\title{
Academic Supervision To Improve Teacher's Performance in Elementary School
}

\author{
Ambar Nur Asih \\ Teacher at Putra Wijaya Elementary School \\ College Student at Postgraduate UNESA \\ Surabaya, Indonesia \\ ambarnurasih@yahoo.com
}

\author{
Erny Roesminingsih \\ Head of Education Management Department UNESA \\ Lecturer at Postgraduate UNESA \\ Surabaya, Indonesia \\ ernyroesminingsih@unesa.ac.id
}

\begin{abstract}
Supervision has become a cross-cutting edge tool and a pivot around which performance revolves. There are widespread and on-going debates centered on the influence of effective supervision on academic performance in our academic. This study examined the role of supervision in academic performance in Elementary School. The study was based on the collegial model of educational management and the supervision model, Theory Y, as proposed by Douglas McGregor. This study employed the descriptive research survey design. Through questionnaire, the data analyzed were collected from 223 respondents who were purposively selected from randomized schools in each region comprising, their assistants and heads of department of 155 schools. The results $(2017$ and 2018) of the sampled schools were analyzed. The reliability coefficient of the questionnaire was alpha 0,826. The Statistical Product and Service Solutions (SPSS) version 18 software were employed in the analyses of data using, mean, standard deviation, correlation, and independent $t$-test. The study revealed that there was a positive weak significant relationship between the supervision roles of heads and academic performance of students. There was positive weak significant relationship between the gender of the headmasters and their supervisory roles. The study recommended that the supervision will be intensified in Putra Wijaya Elementary School. Moreover, the headmaster of elementary school should be reorientated into the new trends of supervision in schools.
\end{abstract}

Keywords-Academic performance; educational management; gender; Heads of School; supervision

\section{INTRODUCTION}

Supervision in Elementary School has become topical as people have attempted to draw strong relationships between effective supervision of the heads and the academic performance of students. Discourse in the supervisory roles of headmasters in elementary school must not be treated lightly to its consequences on academic performance. Many teachers have been conducted supervision in those schools but none of them touched on the role of its effect on academic performance at Elementary School in Surabaya. It is against this background and its associated consequences in which this study is undertaken. Supervision is an intervention that is provided by a senior member of a profession to a junior member or any members of the same profession.
The relationship was evaluated and extended over time. Moreover, it has the simultaneous purpose of enhancing the professional functioning of the junior professionals in monitoring the quality of professional services offered to the clients that she, he or they see, and in serving as a gatekeeper of those who enter the particular professions (Bernard \& Goodyear, 2004). The heads in the Elementary School do not only serve as senior professionals providing intervention to their teachers. They are also mandated to superintend over all other activities of the school although academic work still becomes the central activity. Supervision here is viewed as a mean or process to an end.

The statement is supported by Brinker (2008) who has a notion that supervisors are expected to assess the extent to which educational objectives are actually being realized in order to collect some data in terms of the previously stated objectives in which some judgment can be evaluated.

A research shows that, often times in Surabaya, parents have worked hard to get their wards into certain particular schools such as mission and private schools because of their sterling academic performance which are considered as the outcomes of vigorous and effective supervision. Even though the fact remains that effective supervision is arbitrary, its ending effect affects society.

Neagley (1998) stated that the effective supervision requires a high level of leadership. It is, therefore, worth to undertake such a study dealing with the issue. The purpose of this study deals with the heads including the Headmasters and the Heads of Departments of Elementary School in Surabaya. This research is uniquely positioned to fill in the gaps in effective supervision issues in Elementary School in Surabaya. This research and its discussions on effective supervision are only addressed to either show commitment of the government or appear when the educational issues crop up. In 2017, the Deputy Minister of Education addressed an issue on supervision due to an eminent issue on performance evaluation (The Ghanaian Times, 2017). Other similar studies have also reported differences in terms of supervision and other constructs (Anderson\&Abrokwa,2016). The research made use of a descriptive survey research design to answer three research hypotheses. Again, it was revealed that there was a statistically significant relationship between supervision and gender of the heads of Senior High Schools in Surabaya. Finally, the 
research analysis indicated that there was no statistically significant difference among the categories of the headmasters.

Glickman (1998:2) explains that: "Academic supervision is the function of schools aimed at enhancing and improving the quality of learning through supervisory activities by providing direct assistance to teachers, curriculum developments training, development groups, and action research".

Brigs (1998:43) states that academic supervision deals with stimulating and directing the development of teachers. Trough his opinion, it can be interpreted that academic supervision is an educational supervision activity which coordinate, stimulate and direct the development of teachers. Neagley and Evan (Haiman, 2007:43) asked the statement which says "Academic supervision is the assistance provided for teachers to improve the quality of learning, education, and curriculum".

Glickman (1985:5) on Bafadal states that "academic supervision or supervision of teaching is the effort made to help teachers to be willing to continue learning to improve the quality of learning".

Lovell and Wiles (Daryanto,2013:149) explain that "academic supervision is an attempt to improve the situations of teaching and learning, foster the creativity of teachers, provide support and engage teachers in school activities".

While Daresh (Pupuh Fathurrohman and Suryana. 2011: 30) explains that the concept of academic supervision is the statement saying that "academic supervision is an effort to help teachers develop the ability in order to achieve the goal of teaching". Such opinion can be interpreted that academic supervision is an effort to help teachers develop their abilities so that they can achieve their teaching goals.

Alfonso (Fathurrohman and Suryana, 2011:41) explain academic supervision is "planned and organized activities directly addressed to the effects of the behavior of teachers by providing opportunities for students to learn and try to achieve the goals that have been determined".

In line with the definition of academic supervision above, the academic supervision itself has three keys of definition as explained by Theo (Suryana. 2011:41). They are 1) academic supervision should directly affect and develop the behavior of teachers in managing the learning process, 2) academic supervision is a shared responsibility between the supervisors and teachers, and 3) academic supervision should be able to make more competent teacher.

From the keys of definition above, it can be interpreted that the first supervision academic has to directly influence and develop teachers' behaviors in managing the learning process. It deals with the essential characteristic of academic supervision. In connection to that, it is better for not assuming narrowly that there is only one best way which can be applied in all activities of developing teacher's behavior. There is no academic supervision behavior which is simultaneously good and suitable for all teachers. Strictly speaking, the level of ability, needs, interests, and professional maturity as well as the characteristics of other teachers have to be the basic consideration in developing and implementing a supervision of academic program in education.
Secondly, the behaviors of the internal supervisors help teachers to develop their capabilities that need to be designed in an official rule, so the start time and the end time of the development program is clear. The design is manifested in the form of academic supervision programs leading to certain goals. Since academic supervision is the joint responsibility between supervisors and teachers, it would be nice if the program is designed jointly by the supervisors and the teachers themselves.

Third, the ultimate goal of academic supervision is to make the teacher perform better in facilitating learning for students. Good academic supervision has to be able to make the teachers more competent. Therefore, the teachers will increase their mastery of competence, good personality competency from other teachers, pedagogic competence, professional competence, and also social competence.

The core of academic supervision, in general, essentially empties into supervising the academic things because of the organization education at school. Furthermore, the main activity deals with the academic activity such as activities in managerialism of administration, the instrument of which is used to achieve the objective of the activities conducted. It is important to see the significance of the academic supervision in the process of organizing education at school. In addition, academic supervision has some functions including curriculum development, improvement of the learning process, and profession development within the implementation of the learning programs. Thus, academic supervision is a field of supervision which relates to academic activities carried out in educational units. Such units lead to teacher guidance and supervision in connection to the quality of the teachers' teaching and proficiency when they are carrying out the teaching and learning process. The difference with managerial supervision is related to the supervision of the headmaster.

\section{A. Problem statement}

In spite of the efforts done by Surabaya Education in improving general supervision in schools, in Putra Wijaya elementary school mostly, a large amount of work needs to be done. Informal discussion among people in the community and related research findings (Oduro, 2008: Opare, 1999) explained that poor students' performance in public schools is part of the result of ineffective supervision for teachers. Up to today, there is no empirical evidence about the effectiveness of supervision in Elementary School. Generally, the claim that there is poor supervision of teachers in public schools in this school, is based on assumptions. This study sought to find out the role of effective supervision on academic performance of Elementary Schools in Surabaya from 2015-2017 until 2018.

\section{B. Hypotheses}

i. There is no statistically significant influence of supervision on the academic performance of the Elementary Schools in Surabaya as institutions.

ii. There is no statistically significant correlation between the administrative task of supervision and the gender of the heads of the Elementary Schools in Surabaya. 
iii. There is no statistically significant difference among the category of school heads in relation to the academic performance of the Elementary Schools in Surabaya.

\section{Review of Related Literature}

The study was premised on two key theoretical frameworks: Collegial Supervision and Theory Y.

Heads or headmasters of schools cannot work in isolation and they cannot have a field day to supervise all other things without having to supervise their staffs, especially, the teachers. More than a few authorities in the area of supervision recommend collegial processes as options for teacher supervision (Glatorn, 1998 on Starratt 2008). They believed that promoting collegiality among teachers was an important way to help schools change for the better. According to them, collegial supervision refers to "the existence of high levels of collaboration between teachers, between teachers and school principals, which are characterized by mutual respect, shared work values, cooperation, and specific conversations about teaching and learning" (Sergiovanni \& Starratt, 1993:103). They explained that cooperative professional development is a process of fostering teacher development through systematic collaboration with peers in which it includes a variety of approaches such as professional dialogue, curriculum development, peer observations and feedback, and action research projects. Furthermore, they affirmed that this process includes 39 variety of approaches such as professional dialogue, curriculum development, peer observations, feedback, and also action research. One key question that remains is how collegiality can promote effective academic performance. It is one thing having teachers and heads to work together and do some other things leading the cooperation to best practices and good academic output.

A good practiced collegial supervision can involve a sort of action research between the supervisor and the teacher whereby they pose a hypothesis experiment and implement strategies towards the reasoned solutions (Gebhardion, 2011). The time and the factor of some heads who have been seen very autocratic in their supervision, make all other roles, including students, have to take the 'back seat'. In addition, comparing notes can be very helpful since supervision is primarily concerned with improving classroom practices for the benefit of the students regardless of what may be entailed. JoHones (2010), in his assertion, states that an effective and efficient principal has to be between a learning officer and a coach, an architect and an ideal person, a leader of leaders and teachers. He continued to buttress his assertion by confirming: "The principal must possess certain qualities to reach the acme of success, the secondary education needs a lot of changes and the school principal is likely to be the key agent that such changes are introduced and sustained. He is responsible for the smooth running of the school. His challenge therefore is to ensure that all children reach the levels of academic achievements. This he achieves by setting instructional methods for the attainment of school goals" (Kelechukwu, 2011:20).
Principalship of schools in Nigeria has evolved from the position and performance of teachers (Aderounmu \& Ehiametalor, 1985). Such position proposed by Ehiametalor was after that confirmed by Bays (2011) who states that it occurs as far as collegial supervision is concerned. Even though that model may have its inherent weaknesses of having to work in a group, Goldhammer (1998) stands by the conjectures that the most telling mark of some practitioners' commitment and fitness to perform professional work is the readiness to have such work examined and critiqued by other competent workers.

\section{Theory $Y$}

Generally speaking, McGregor's Theory $\mathrm{X}$ and $\mathrm{Y}$ were not developed for the educational areas. They were propounded for the industrial sector. However, it does not mean that it is impossible to make use of his theoretical concepts in educational management. The theories can be modified to suit the educational situations based on the assumptions that the student cannot be considered as a worker and the classroom cannot be considered as a factory. Additionally, there are differences between teacher-student relationship and managerworker relationship.

In adaption of Theory $\mathrm{Y}$ to the educational settings, they concern with the students and hold that them so that they will practice doing self-direction if they are committed to the objective and the students' learning of accepting and seeking for responsibility.

These assumptions, when considered for effective supervision by heads and seen as the roles and position of Elementary School students, will support Ukje's (1998) view that roles are the images held for an individual's relational behaviors when that individual is doing activities in a particular position. The role describes a set of expectations that people in the organization have of an individuality in doing his or her job (Kelechukwu:2011).

To spice it up, there are some levels of supervision, and others believe that the purpose of supervision is helping teachers to be aware of their teaching and its consequences for their learners (Glickman, Gordon \& Gordon, 1998; Nolan, 1997). Some researchers have also hypothesized that supervision is an act of encouraging human relations (Wiles \& Bondi, 1996) and teacher motivation (Glickman, Gordon \& Gordon, 1998) on Brave (2011), as well as enabling teachers to try out new instructional techniques in a safe, supportive environment (Nolan, 1997). Those authorities failed to see the student (supervisee) factor in supervision. As an effect of it, supervision of teachers is meant to yield positive results in the learning outcomes of the students.

\section{E. Effective Supervision}

Nolan and Francis (1992) saw supervision to provide a mechanism for teachers and supervisors to increase their understanding of the teaching-learning process through collective inquiry with other professionals. The purposes of the supervision provided by these researchers can be grouped under the following themes: improving fostering curriculum and staff development; encouraging human relations and 
motivation; and encouraging action research as well as supporting collaboration (Baffour-Awuah, 2011).

According to Baffour-Awuah, supervision was initially described as inspection which has the connotation of direct control towards teachers and it was done by the school inspectors. The term supervision has been gradually taken over inspection, but both terms are sometimes used together. Frontier and Livingston (2011) explain that the clergy among the first supervisors used in schools and these individual supervisors are charged with monitoring the quality of instruction. Those supervisors have nearly unlimited power to establish criteria for effective instruction to hire and fire teachers (Burke\& Krey,2005).

Because there was not necessary agreement to the importance or the nature of pedagogical expertise, the quality, and type of feedback to teachers which was highly vary (Frontier and Livingston, 2011).

An effective supervision by Gordon (2004), requires welltrained person with knowledge, interpersonal skills and technical skills who is prepared to provide necessary and appropriate guidance and support to the teaching staffs. Effective supervision should result in growth and learning conducted by the teacher (Duke, 2008:5). Some researchers have defined effective supervision in many ways dealing with education. Jones (1993) states that effective supervision is vital in order to look at what actually happens in the classroom. Collaboratively, Brennen (2008) states that an effective supervisor is the one who links interpersonal with technical skills and successfully improves instruction. As a result, not all supervisors can be effective in all supervisory processes.

A lot of factors, including supervision, affect academic performance but those factors vary from person to person and from country to country (Shachar \& Neumann, 2010), and sometimes it is based on the administrative styles of school heads. Meanwhile, teachers' performance depends on several factors such as learning facilities and gender to age differences which identifies four other factors that affect students' academic performance.

The factors are students' communication skills, learning facilities, proper guidance, and family stress. Some other researchers used test results or previous year results since they were studying performance for the specific subject or year (Hijazi,2006). Furthermore, research studies show that learners' academic accomplishments and activities, perceptions of their coping strategies and positive attributions, and background characteristics, were indirectly related to their composite scores known through the academic achievement in high schools (Noble \& Sawyer, 2006). In brief, there are a lot of factors that potentially pose threat dealing with academic performance of students but none of them touched the area of effective supervision on academic performance in Elementary School.

Azure (2016, 163), in his study, looked at the "elements of effective supervision from Ghanaian graduate students' perspective" and found no significant difference between effective supervision and gender. His findings are in line with findings from the third hypothesis of this research. In their research which sought to find "strategies for improving", Maimela and Monyatsi (2016) only found "parental involvement, infrastructure provision, and human resources" as the factors influencing academic performance. Therefore, this research is expected to find a way out of such confusion, in which earlier research conclude that effective supervision is very important fo academic performance which is in contrast to Maimela and Monyatsi's (2016) findings.

\section{METHOD}

\section{A. Research design}

A descriptive survey research design was used in this study. Meanwhile, the data were collected through questionnaire from 155 Elementary Schools across Ghana which were randomly selected from all the 10 regions of the country, following Category of School dealing with the belonging supervision. Best and Khan (1998) explain that descriptive research concerned with the conditions or correlation that exist, such as determining the nature of prevailing conditions, practices and attitudes; opinions that are held; processes that are going on; and/or trends that are developed. The sample size involved 150 participants including the headmasters, the assistant and heads of Departments who were selected purposively. A total number of 1035 copies of questionnaires were distributed and 150 $(88.75 \%)$ out of all the questionnaires distributed were returned.

\section{B. Population}

All the 10 regions were involved in this study. The respondents were categorized into five categories namely, Category A, Category B, Category C, Category D, and Category $\mathrm{T}$. The number of male respondents were 105 $(64.1 \%)$ while the rest $55(35.9 \%)$ were females. The respondents were in the age brackets of 10 years. Most of the respondents were titled Bachelors's Degree shown by the number of $113(65.4 \%)$. Meanwhile, 110 (34.3\%) respondents had their Master's Degree with 3 (0.35) of them were running their postgraduate study. In terms of location, there were 102 $(81.8 \%)$ of the respondents located in the urban areas with the rest of them, shown by number $175(18.2 \%)$, were located in the rural areas.

\section{Statistical analysis tool}

The Statistical Product and Service Solutions (SPSS) software was employed in the process of analyzing data by using percentages, mean, standard deviation, correlation, and independent t-test. A pilot test that was conducted on the questionnaire returned a reliability coefficient of $(\alpha)=0.826$.

\section{ANALYSIS, RESUlt AND DiscuSSIONS}

Finally, the complete content and organizational editing were done before formatting. It is important to take note of the following items while proofreading the spelling and grammar: 


\section{A. Abbreviations and Acronyms}

Hypotheses 1: There is no statistically significant influence of supervisions towards the academic performance of Putra Wijaya Elementary School compared to the other elementary schools.

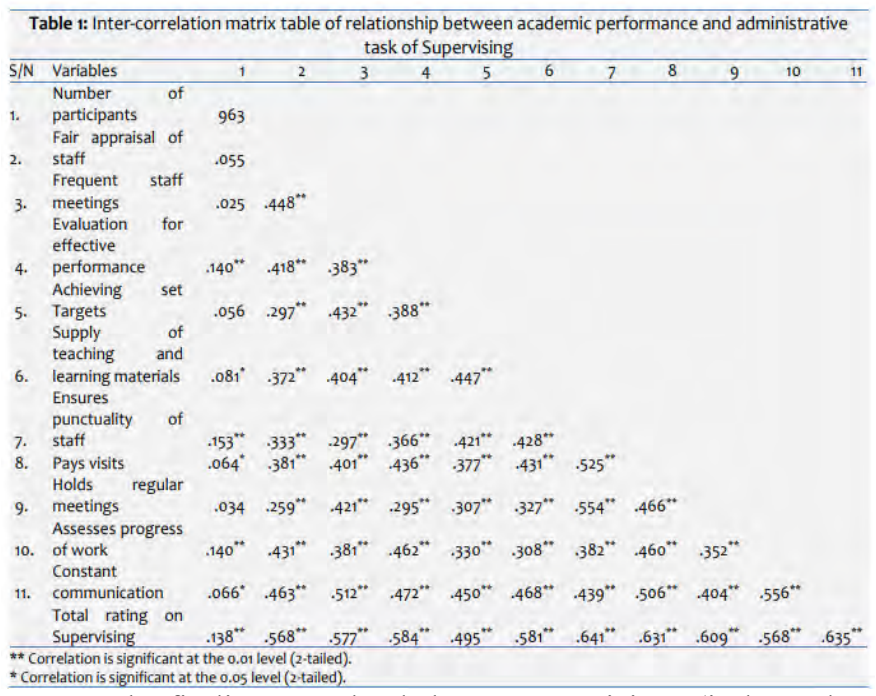

Such finding revelaed how supervision (independent variable) relates to the dependent variable, Supervision: $r(963)$ $=0.138, \mathrm{p}>0.05$. In relation to the hypothesis one $(\mathrm{H} 1)$, since it was observed that academic performance had a weak but positive relationship of 0.138 with a $p<0.05$ and the relationship was significant. Therefore, the null hypothesis (H0 1) was rejected but the alternate hypothesis (H11) was maintained.

There were positive influences of supervision on the academic performance of Elementary Schools in Surabaya. It also meant that, based on the results, the decisions based on supervision affected the academic performance of students. Since the effect of supervision in schools need to lead to academic performance, it was likely that heads did not really understand their roles as supervisors because the results contradicted to Nolan and Francis (1992) assertion which explains that supervision provides a mechanism for teachers and supervisors to increase their understanding of the teaching-learning process through collective inquiry with other professionals.

Even though the respondents did actions in terms of their capacities as heads, on the flip side, one may agree that they lacked of requisite training or professional skills in supervision. Such idea is in line with Gordon (2004) who posits that supervision requires well-trained personnel with knowledge, interpersonal skills, and technical skills who are prepared to provide the necessary and appropriate guidance and support to the teaching staff.

Hypotheses 2: There is no statistically significant relationship between administrative task of supervision and gender of the teachers in Elementary Schools in Surabaya. An independent samples $t$-test was conducted to compare correlation betweenthe administrative task of supervision and the gender of the heads of Putra Wijaya Elementary School in Surabaya.

\begin{tabular}{llrrrrr}
\hline \multicolumn{7}{c}{ Table 2: Independent sample t-test } \\
\hline Variable & Gender & N & Mean & Std. Dev. & t-value & p-value \\
\hline Supervision & Male & 617 & 4.61 & .604 & & -2.602 \\
& Female & 346 & 4.71 & .515 & & .009 \\
\hline
\end{tabular}

There was a statistically significant difference in the administrative roles of the heads dealing with the gender which concerned on male $(\mathrm{M}=4.61, \mathrm{SD}=.60)$ and female $(\mathrm{M}=4.71, \mathrm{SD}=.52) ; \mathrm{t}(963)=-2.602, \mathrm{p}=.009$. From the results, it can be seen that there was statistically significant correlation between supervision and gender of heads of Putra Wijaya Elementary School in Surabaya. The gender base difference was noted in the supervision roles of heads in the Elementary School. The female supervisors, who were also heads, performed better than the males, hence, hypothesis 2 was rejected.

The finding of this study was in contrast to the previous study done by Cole (1996) which found no differences between male and female leadership behaviors in motivation as well as their attitude including the ability to motivate the team and the general work performance. Currently, in Surabaya, most of the Elementary schools in A and B category are headed by females. The academic performance of those schools has been very good. Such finding can be the basis of conclusion stating that female heads were very special with their supervisory roles.

Hypotheses 3: There is not statistically significant effect of the category of school heads towards the academic performance of Putra Wijaya Elementary School in Surabaya.

\begin{tabular}{lrrrrr}
\hline \multicolumn{5}{c}{ Table 3: ANOVA for the differences among the categories of heads on academic performance } \\
\hline Source of variation & Sum of Squares & df & Mean Square & $F$ & Sig. \\
\hline Between Groups & 94314.970 & 2 & 47157.485 & 1.702 & .183 \\
Within Groups & $2.660 \mathrm{E} 7$ & 960 & 27706.683 & & \\
Total & $2.669 \mathrm{E} 7$ & 962 & & & \\
\hline
\end{tabular}

There is no statistically significant difference among the various categories of heads $F(2,960)=1.702, p=.183$. We failed to reject the null hypothesis stating that there is no statistically significant difference among the category of school heads and academic performance Elementary School in Surabaya. Furthermore, it implies that the being a headmaster, an assistant headmaster, or a head of department did not affect the academic performance of Putra Wijaya Elementary School in Surabaya.

\section{CONCLUSIONS AND RECOMMENDATIONS}

The study revealed that there is a statistically significant relationship between the heads' supervision roles and the academic performance of the students. Furthermore, this study found that there was a statistically significant relationship between gender of the heads and their supervisory roles. In addition, female supervisors performed better than their male counterparts. Finally, it was found out that there was no difference in terms of the supervision roles among the category of school heads and the academic performance of Putra Wijaya Elementary School students. Therefore, the 
researchers recommended that supervision will be intensified in all Elementary School.

Headmasters of Elementary School should be reorientated into the new trends of supervision in schools. Furthermore, pre-head training needs to be emphasized by the IKIP. Moreover, there should be collaboration between the Ministry of Education and other stakeholders in designing a standardized handbook for heads of Elementary School. Conscious efforts need also to be raised in order to encourage females in taking up head positions. The attributes that make female heads perform better than their male counterparts should be studied further to help the males build their capacity. Finally, a lot more females should be encouraged to rise to the head positions.

\section{REFERENCES}

[1] Aderounmu, Ehiametalor.(2005).Introduction to Administration of Schools in Nigeria. Ibadan: Evans Brothers.

[2] Anderson, Donkoh. (2016). Problems of Teaching and Learning in Basic Schools. Case of Ewusa Demonstration Basic School, Ghana. Advances in Social Sciences Research Journal.

[3] Azure.(2016). Students on Perspective of Effective Supervision of Graduate Programmes in Ghana. American Journal of Educational Research,163-169.

[4] Bays. (2011). Supervision of special education instruction in rural public school districts: A grounded theory. Faculty of the Virginia Polytechnic Institute and State University.

[5] Bernard,G.(2004).Fundamentals of Clinical Research in Education. (8th Ed.) Boston: Allyn and Bacon.
[6] Best, Khan.(1998). Research in Education. (8th Ed.) Boston: Allyn and Bacon Clinical supervision and case study.

[7] Burke,K. (2005). Supervision: A guide to instructional leadership (2nd),Illinois:Charles Thomas Publishers.

[8] Daryanto,Rachmawati. (2015). Supervisi dalam Pembelajaran, Yogyakarta: Gava Media.

[9] Glickman, Ross-Gordon. (2008). Instructional Supervision: A Developmental Approach, 4th Boston: Allyn \& Bacon.

[10] Goldhammer. (1980). Clinical Supervision. Special Method for the Supervision of Teachers. New York: Holt, Rinchart and Winston

[11] Jones. (1993) Educational Management V: Human Resources Management EMH 500A 2004 Technikon, Pretoria Journal of Education Administration

[12] Kelechukwu. (2011). Analysis of Administrative Roles of Principals in Private Secondary Schools in Aba Education Zone of Abia State. Continental J. Education Research. 4 (1): 18-27

[13] Maimela,Monyatsi.(2016). Strategies for Improving the Academic Performance of Students in Botswana Primary Schools. World Journal of Educational Research, 3(1), 157.

[14] Neagley,Evans. (1980). Handbook for effective supervision of instruction (3rd ed.). New Jersey: Prentice-Hall Inc.

[15] Nolan. (1997). Can a supervisor be a coach? No. In J. Glanz \& R. F. Neville (Eds.), Educational supervision: Perspectives, issues, and controversies (pp. 100-112). Norwood, MA: ChristopherGordon.

[16] Pupuh, Suryana.(2011).Supervisi Pendidikan, Bandung: Rafika Aditama

[17] Sergiovanni, Starratt. (1993). Supervision: A redefinition. New York: McGraw-Hill.

[18] Theo, Haimann.(1987).Supervision Concepts and Practices of Management, Ohio: South-Western Publishing

[19] Wiles, Bondi, (1996). Supervision: A guide to practice (4th). Englewood Cliffs,N.J.Merrill. 